\title{
Chronology of 1960s American Culture
}




\begin{tabular}{|c|c|c|c|c|}
\hline Date & Events & Music & Performance & Literature \\
\hline 1960 & $\begin{array}{l}\text { President Eisenhower } \\
\text { signs Civil Rights } \\
\text { Act. } \\
\text { John F. Kennedy } \\
\text { defeats Richard } \\
\text { Nixon in Presidential } \\
\text { election by small } \\
\text { margin. } \\
\text { Kennedy emphasises } \\
\text { a cultural 'New } \\
\text { Frontier' on } \\
\text { inauguration. } \\
\text { Four black students } \\
\text { from North Carolina } \\
\text { A \& T stage a sit-in at } \\
\text { Woolworths } \\
\text { segregated lunch } \\
\text { counter, Greensboro, } \\
\text { NC. } \\
\text { The Student Non- } \\
\text { violent Co-ordinating } \\
\text { Committee (SNCC) } \\
\text { founded, Raleigh, } \\
\text { NC. } \\
\text { Oral contraceptive } \\
\text { approved for sale. } \\
\text { Caryl Chessman's } \\
\text { execution. }\end{array}$ & $\begin{array}{l}\text { Stax Records } \\
\text { founded in } \\
\text { Memphis. } \\
\text { John Hammond } \\
\text { signs Dylan to } \\
\text { Columbia. } \\
\text { Alan and John } \\
\text { Lomax, Folk Songs } \\
\text { of North America } \\
\text { Bob Thompson, } \\
\text { Gardens of Music }\end{array}$ & $\begin{array}{l}\text { Kennedy and Nixon } \\
\text { participate in first } \\
\text { televised debates } \\
\text { between Presidential } \\
\text { candidates } \\
\text { Edward Albee, The } \\
\text { American Dream } \\
\text { The Fastasticks, Off- } \\
\text { Broadway } \\
\text { Bye-Bye Birdie, on } \\
\text { Broadway }\end{array}$ & $\begin{array}{l}\text { John Barth, The Sot- } \\
\text { weed factor } \\
\text { Richard Yates, } \\
\text { Revolutionary Road } \\
\text { John Updike, Rabbit } \\
\text { Run } \\
\text { Harper Lee, To Kill } \\
\text { A Mockingbird } \\
\text { Robert Lowell wins } \\
\text { National Book } \\
\text { Award for Life } \\
\text { Studies }\end{array}$ \\
\hline 1961 & $\begin{array}{l}\text { Alan Shepard first } \\
\text { American in space; } \\
\text { Soviet astronaut Yuri } \\
\text { Gagarin first person } \\
\text { to orbit earth. } \\
\text { President Kennedy } \\
\text { establishes the Peace } \\
\text { Corps. } \\
\text { Kennedy requires } \\
\text { federal contractors to } \\
\text { take 'affirmative } \\
\text { action' to ensure } \\
\text { individuals treated } \\
\text { without regard to } \\
\text { race. } \\
\text { CORE organises } \\
\text { Freedom Rides. } \\
\text { Birth-control pill } \\
\text { comes into general } \\
\text { use. }\end{array}$ & $\begin{array}{l}\text { Ray Peterson, Tell } \\
\text { Laura I Love Her } \\
\text { Motown signs The } \\
\text { Supremes } \\
\text { Ben E. King, 'Stand } \\
\text { By Me' } \\
\text { 'I Fall To Pieces' by } \\
\text { Patsy Cline is } \\
\text { crossover hit }\end{array}$ & $\begin{array}{l}\text { Camelot on } \\
\text { Broadway } \\
\text { Edward Albee, } \\
\text { Whose Afraid of } \\
\text { Virginia Woolf? } \\
\text { Tennessee Williams, } \\
\text { Period of } \\
\text { Adjustment } \\
\text { How To Succeed in } \\
\text { Business Without } \\
\text { Really Trying }\end{array}$ & $\begin{array}{l}\text { Joseph Heller, } \\
\text { Catch-22 } \\
\text { Henry Miller Tropic } \\
\text { of Cancer unbanned } \\
\text { and published in US } \\
\text { Kurt Vonnegut, } \\
\text { Cat's Cradle } \\
\text { Walker Percy, The } \\
\text { Moviegoer }\end{array}$ \\
\hline
\end{tabular}




\begin{tabular}{|c|c|c|c|}
\hline Film & Television & Art & Criticism \\
\hline $\begin{array}{l}\text { Psycho } \\
\text { Primary } \\
\text { The Apartment } \\
\text { Sergeant Rutledge } \\
\text { The Alamo }\end{array}$ & $\begin{array}{l}\text { Andy Griffiths Show } \\
\text { The Ed Sullivan Show } \\
\text { disallows Dylan from } \\
\text { singing 'Talking John } \\
\text { Birch Paranoid Blues' } \\
\text { Hanna-Barbera's The } \\
\text { Flintstones } \\
\text { Route } 66 \text { premieres on } \\
\text { CBS }\end{array}$ & $\begin{array}{l}\text { Museum of Modern } \\
\text { Art, 'Art of } \\
\text { Assemblage' } \\
\text { Jasper Johns, Painted } \\
\text { Bronze } \\
\text { Robert Ryman, 'White } \\
\text { Paintings' including } \\
\text { Untitled } \\
\text { Allan Kaprow, Car } \\
\text { Crash: Happening } \\
\text { Jim Dine, 'The Car } \\
\text { Crash' } \\
\text { Andy Warhol, Dick } \\
\text { Tracy }\end{array}$ & $\begin{array}{l}\text { John F. Kennedy, } \\
\text { Strategy of Peace } \\
\text { Paul Goodman, } \\
\text { Growing Up Absurd } \\
\text { Barry Goldwater, The } \\
\text { Conscience of a } \\
\text { Conservative } \\
\text { Leslie Fiedler, Love } \\
\text { and Death in the } \\
\text { American Novel } \\
\text { Daniel Bell, The End of } \\
\text { Ideology } \\
\text { Wallace Stegner, } \\
\text { 'Wilderness Letter' } \\
\text { C. Wright Mills, Listen } \\
\text { Yankee }\end{array}$ \\
\hline
\end{tabular}

Shadows

Breakfast at Tiffany's

A Raisin in the Sun

The Misfits

West Side Story
Newton Minnow

refers to television as a

'Vast Wasteland'

President Kennedy

holds first televised

press conference

$M r E d$ debuts

Car 54 Where Are

You? on NBC
William Anders'

photograph of earth

from moon: Earthrise

Martha Jackson gallery,

'Environments,

Situations, Spaces'

(including Allan

Kaprow's Yard)

Cy Twombly, Bay of

Naples

Dennis Hopper's

photograph Double

Standard
Marshall McLuhan,

The Gutenberg Galaxy

Clement Greenberg,

Art and Culture

Lewis Mumford, The

City in History

William F. Buckley, $U p$

From Liberalism

Wayne Booth, The

Rhetoric of Fiction 


\begin{tabular}{|c|c|c|c|c|}
\hline Date & Events & Music & Performance & Literature \\
\hline 1962 & $\begin{array}{l}\text { The Soviet Missile } \\
\text { Crisis. } \\
\text { US intervention in } \\
\text { Cuba known as the } \\
\text { Bay of Pigs invasion } \\
\text { fails. } \\
\text { US explodes nuclear } \\
\text { device near Christmas } \\
\text { Island. } \\
\text { Kennedy sends } \\
\text { Special Forces troops } \\
\text { to Vietnam to fight } \\
\text { alongside ARVN } \\
\text { troops. } \\
\text { US Air Force first } \\
\text { uses Agent Orange. } \\
\text { SDS holds first } \\
\text { national convention, } \\
\text { Port Huron, } \\
\text { Michigan. } \\
\text { James Meredith } \\
\text { desegregates } \\
\text { University of } \\
\text { Mississippi. } \\
\text { Richard Nixon } \\
\text { announces departure } \\
\text { from politics. }\end{array}$ & $\begin{array}{l}\text { Bob Dylan, Bob } \\
\text { Dylan (debut album) } \\
\text { Carla Thomas; 'Gee } \\
\text { Whiz' } \\
\text { Ray Charles, 'I } \\
\text { Can't Stop Lovin' } \\
\text { You' } \\
\text { Booker T. and the } \\
\text { MGs, 'Green } \\
\text { Onions' }\end{array}$ & $\begin{array}{l}\text { Edward Albee, } \\
\text { Who's Afraid of } \\
\text { Virginia Woolf? on } \\
\text { Broadway } \\
\text { A Funny Thing } \\
\text { Happened on the } \\
\text { Way to the Forum } \\
\text { Cole Porter's } \\
\text { 'Anything Goes' } \\
\text { revived Off- } \\
\text { Broadway }\end{array}$ & $\begin{array}{l}\text { Philip Roth, Letting } \\
\text { Go } \\
\text { Edward Albee, } \\
\text { Who's Afraid of } \\
\text { Virginia Woolf? } \\
\text { Ken Kesey, One } \\
\text { Flew Over the } \\
\text { Cuckoo's Nest } \\
\text { Flannery O'Connor, } \\
\text { Wise Blood }\end{array}$ \\
\hline
\end{tabular}




\begin{tabular}{|c|c|c|c|}
\hline Film & Television & Art & Criticism \\
\hline $\begin{array}{l}\text { Advise and Consent } \\
\text { Marilyn Monroe dies } \\
\text { To Kill A Mockingbird } \\
\text { The Manchurian } \\
\text { Candidate } \\
\text { Promises! Promises! } \\
\text { That Touch of Mink } \\
\text { Days of Wine and } \\
\text { Roses }\end{array}$ & $\begin{array}{l}\text { Launch of the satellite } \\
\text { Telstar } \\
\text { Adam Clayton Powell, } \\
\text { Sidney Poitier, Dick } \\
\text { Gregory and others } \\
\text { testify to racial } \\
\text { discrimination to } \\
\text { House Committee on } \\
\text { Labor and Education } \\
\text { The Tonight Show } \\
\text { Starring Johnny } \\
\text { Carson } \\
\text { The Beverly Hillbillies } \\
\text { premieres on CBS } \\
\text { Hanna-Barbera's The }\end{array}$ & $\begin{array}{l}\text { Artforum inaugurated } \\
\text { Castelli Gallery, 'Roy } \\
\text { Lichtenstein' } \\
\text { Roy Lichtenstein, } \\
\text { Masterpiece } \\
\text { 'The New Realists' } \\
\text { Andy Warhol, Marilyn } \\
\text { Gold and Marilyn } \\
\text { Diptych } \\
\text { Diane Arbus, Child } \\
\text { With a Toy Hand } \\
\text { Grenade in Central } \\
\text { Park, New York City }\end{array}$ & $\begin{array}{l}\text { Rachel Carson, Silent } \\
\text { Spring } \\
\text { Michael Harrington, } \\
\text { The Other America } \\
\text { The Port Huron } \\
\text { Statement } \\
\text { Dwight MacDonald, } \\
\text { Against the American } \\
\text { Grain: Essays on the } \\
\text { Effects of Mass Culture } \\
\text { James Baldwin, 'Letter } \\
\text { From a Region of My } \\
\text { Mind', New Yorker } \\
\text { Robert F. Williams, } \\
\text { Negroes With Guns }\end{array}$ \\
\hline
\end{tabular}




\begin{tabular}{|c|c|c|c|c|}
\hline Date & Events & Music & Performance & Literature \\
\hline 1963 & $\begin{array}{l}\text { Voter-registration } \\
\text { drive begins in } \\
\text { Mississippi. } \\
\text { NAACP's Medgar } \\
\text { Evers murdered in } \\
\text { Mississippi by Byron } \\
\text { de la Beckwith. } \\
\text { March on Washington } \\
\text { for Jobs and Freedom } \\
\text { featuring King's 'I } \\
\text { Have A Dream' } \\
\text { speech. } \\
\text { Nuclear test-ban } \\
\text { treaty signed by US, } \\
\text { UK and USSR. } \\
\text { Bomb kills four black } \\
\text { schoolgirls at church } \\
\text { in Birmingham, AL. } \\
\text { President Kennedy } \\
\text { assassinated, Dallas, } \\
\text { Texas. } \\
\text { Jack Ruby murders } \\
\text { Lee Harvey Oswald, } \\
\text { jailed for Kennedy's } \\
\text { murder. } \\
\text { National Commission } \\
\text { on the Causes and } \\
\text { Prevention of } \\
\text { Violence established. } \\
\text { Buddhist monk self- } \\
\text { immolates in Saigon } \\
\text { to protest anti- } \\
\text { Buddhist policies. } \\
\text { University of } \\
\text { Alabama desegregated } \\
\text { while George Wallace } \\
\text { 'stands in } \\
\text { schoolhouse door'. }\end{array}$ & $\begin{array}{l}\text { Dylan's first album, } \\
\text { The Freewheelin' } \\
\text { Bob Dylan } \\
\text { Nina Simone, } \\
\text { 'Mississippi } \\
\text { Goddamn' } \\
\text { James Brown, Live } \\
\text { at the Apollo } \\
\text { John Coltrane, Live } \\
\text { at Birdland }\end{array}$ & $\begin{array}{l}\text { Dylan duet of 'We } \\
\text { Shall Overcome' } \\
\text { with folk hero Pete } \\
\text { Seeger at the } \\
\text { Newport Folk } \\
\text { Festival } \\
\text { Dylan's 'Blowin' in } \\
\text { the Wind' } \\
\text { performed at March } \\
\text { on Washington } \\
\text { Cassius Clay, The } \\
\text { Greatest } \\
\text { Oliver! Broadway's } \\
\text { most popular show }\end{array}$ & $\begin{array}{l}\text { Sylvia Plath, Ariel } \\
\text { Sylvia Plath, The } \\
\text { Bell Jar } \\
\text { Norman Mailer, An } \\
\text { American Dream } \\
\text { Sylvia Plath, } \\
\text { 'America! America!' } \\
\text { Howard Nemerov is } \\
\text { poet laureate }\end{array}$ \\
\hline
\end{tabular}




\begin{tabular}{|c|c|c|c|}
\hline Film & Television & Art & Criticism \\
\hline $\begin{array}{l}\text { Cleopatra } \\
\text { Hud } \\
\text { Crisis: Behind a } \\
\text { Presidential } \\
\text { Commitment } \\
\text { PT-109 } \\
\text { Shock Corridor } \\
\text { The Thrill of It All }\end{array}$ & $\begin{array}{l}\text { President Kennedy's } \\
\text { address to the nation } \\
\text { on civil rights } \\
\text { WLBT-TV in Jackson, } \\
\text { Mississippi, brought } \\
\text { before Federal } \\
\text { Communications } \\
\text { Commission } \\
\text { Jack Ruby murder of } \\
\text { Lee Harvey Oswald } \\
\text { captured live on TV } \\
\text { Shindig! premieres on } \\
\text { ABC }\end{array}$ & $\begin{array}{l}\text { The Foundation for } \\
\text { Contemporary Arts } \\
\text { established by Jasper } \\
\text { Johns and John Cage } \\
\text { Pasadena Museum, } \\
\text { Marcel Duchamp } \\
\text { retrospective } \\
\text { Guggenheim Museum, } \\
\text { 'Six Painters and the } \\
\text { Object' (Jim Dine, } \\
\text { Jasper Johns, Roy } \\
\text { Lichtenstein, Robert } \\
\text { Rauschenberg, James } \\
\text { Rosenquist, Andy } \\
\text { Warhol) } \\
\text { Andy Warhol, 'Death' } \\
\text { and 'Disaster' series } \\
\text { Ed Ruscha's 26 } \\
\text { Gasoline Stations }\end{array}$ & $\begin{array}{l}\text { Marshall McLuhan, } \\
\text { Understanding Media: } \\
\text { The Extensions of Man } \\
\text { Betty Friedan, The } \\
\text { Feminine Mystique } \\
\text { James Baldwin, The } \\
\text { Fire Next Time } \\
\text { Martin Luther King Jr, } \\
\text { 'Letter from } \\
\text { Birmingham Jail' } \\
\text { Martin Luther King Jr, } \\
\text { Why We Can't Wait: } \\
\text { Chaos or Community? } \\
\text { New York Review of } \\
\text { Books begins } \\
\text { publication }\end{array}$ \\
\hline
\end{tabular}




\begin{tabular}{|c|c|c|c|c|}
\hline Date & Events & Music & Performance & Literature \\
\hline 1964 & 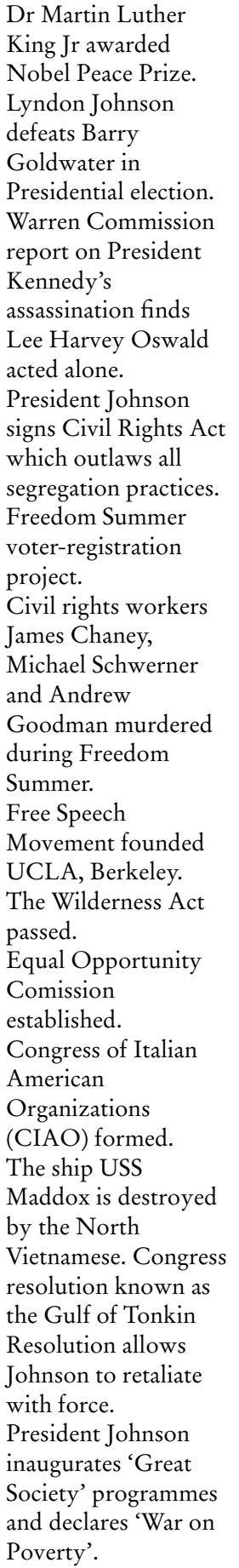 & $\begin{array}{l}\text { The Supremes' } \\
\text { 'Where Did Our } \\
\text { Love Go?' is their } \\
\text { first Billboard no. } 1 \\
\text { The Supremes, } \\
\text { 'Baby Love' } \\
\text { Dylan, 'The Times } \\
\text { They Are } \\
\text { A-Changin' } \\
\text { Meet the Beatles } \\
\text { (released in US) }\end{array}$ & $\begin{array}{l}\text { The Beatles' first } \\
\text { tour of the US } \\
\text { Cassius Marcellus } \\
\text { Clay defeats Sonny } \\
\text { Liston for } \\
\text { heavyweight boxing } \\
\text { title and becomes } \\
\text { Muhamad Ali } \\
\text { Yoko Ono, Cut } \\
\text { Piece premieres in } \\
\text { Japan } \\
\text { Hello Dolly! } \\
\text { premieres on } \\
\text { Broadway }\end{array}$ & $\begin{array}{l}\text { Saul Bellow, Herzog } \\
\text { Thomas Berger, } \\
\text { Little Big Man } \\
\text { Robert Lowell, For } \\
\text { the Union Dead } \\
\text { Amiri Baraka, } \\
\text { Dutchman and The } \\
\text { Toilet } \\
\text { Shirley Ann Grau, } \\
\text { The Keepers of the } \\
\text { House } \\
\text { James Baldwin, } \\
\text { Blues for Mister } \\
\text { Charlie }\end{array}$ \\
\hline
\end{tabular}




\begin{tabular}{llll}
\hline Film & Television & Art & Criticism \\
\hline Mary Poppins & The Beatles debut on & Richard Avedon and & Susan Sontag, 'Notes \\
Dr Strangelove & The Ed Sullivan Show & James Baldwin, & on Camp', Partisan \\
Goldfinger & NBC's I Dream of & Nothing Personal & Review \\
My Fair Lady & Jeannie (1965-70) & Sidney Janis Gallery, & Leslie Fiedler, Waiting \\
Nothing But A Man & Soap opera Days of & 'Four Environments & for the End \\
Cheyenne Autumn & Our Lives begins on & by Four New Realists' & Leo Marx, The \\
& NBC & Andy Warhol, 16 & Machine in the \\
& That Was The Week & Jackies & Garden: Technology \\
& That Was begins in US & Rauschenberg wins & and the Pastoral Ideal \\
& & International Grand & in America \\
& Prize at Venice & Herbert Marcuse, One \\
& Biennale & Dimensional Man \\
& Robert Rauschenberg, & James W. Silver, \\
& Retroactive I and II & Mississippi: A Closed \\
& Edward Keinholz, & Society \\
& Back Seat Dodge-38 & Howard Zinn, The \\
& & & Southern Mystique \\
& & & Ralph Ellison, Shadow \\
& & & and Act
\end{tabular}




\begin{tabular}{|c|c|c|c|c|}
\hline Date & Events & Music & Performance & Literature \\
\hline 1965 & $\begin{array}{l}\text { Malcolm X } \\
\text { assassinated at } \\
\text { Audubon Ballroom, } \\
\text { New York City. } \\
\text { Democrat Party } \\
\text { refuses to seat } \\
\text { Mississippi Freedom } \\
\text { Democratic Party } \\
\text { delegation at the } \\
\text { Convention, Atlantic } \\
\text { City. } \\
\text { 'Bloody Sunday' } \\
\text { attacks in Selma, } \\
\text { Alabama. } \\
\text { Voting Rights Act } \\
\text { signed into law. } \\
\text { SDS protests } \\
\text { Vietnam War in } \\
\text { Washington DC. } \\
\text { Racial disturbances in } \\
\text { Watts, Los Angeles } \\
\text { followed by protests } \\
\text { in Cleveland, } \\
\text { Chicago, Detroit and } \\
\text { other cities. } \\
\text { Operation Rolling } \\
\text { Thunder authorised } \\
\text { to allow aerial } \\
\text { bombardment of } \\
\text { North Vietnam. } \\
\text { American ground } \\
\text { troops sent to fight } \\
\text { the North Vietnamese } \\
\text { Protests against the } \\
\text { draft begin. } \\
\text { Federal law passed to } \\
\text { make destroying draft } \\
\text { card illegal. } \\
\text { Federal Aid to the } \\
\text { Arts Act institutes } \\
\text { National Endowment } \\
\text { for the Humanities } \\
\text { (NEH) and for the } \\
\text { Arts (NEA). }\end{array}$ & $\begin{array}{l}\text { Dylan goes electric } \\
\text { at Newport News } \\
\text { folk festival in July } \\
\text { Jimi Hendrix, } \\
\text { 'Purple Haze' } \\
\text { Tom Paxton, } \\
\text { 'Lyndon Johnson } \\
\text { Told the Nation' } \\
\text { Phil Ochs, 'Draft } \\
\text { Dodger Raag' } \\
\text { Malvina Reynolds, } \\
\text { 'Napalm' } \\
\text { Rolling Stones, } \\
\text { 'Satisfaction' }\end{array}$ & $\begin{array}{l}\text { Ken Kesey and } \\
\text { Pranksters hold first } \\
\text { public 'Acid Test' } \\
\text { Radio stations ban } \\
\text { Rolling Stones' } \\
\text { 'Satisfaction' as too } \\
\text { suggestive }\end{array}$ & $\begin{array}{l}\text { Ronald L. Fair, } \\
\text { Many Thousand } \\
\text { Gone } \\
\text { William Denby, The } \\
\text { Catacombs } \\
\text { James Baldwin, } \\
\text { 'Going to Meet the } \\
\text { Man' } \\
\text { Flannery O'Connor, } \\
\text { Everything That } \\
\text { Rises Must Converge } \\
\text { (posthumous) }\end{array}$ \\
\hline
\end{tabular}




\begin{tabular}{llll}
\hline Film & Television & Art & Criticism \\
\hline \multirow{2}{*}{$\begin{array}{lll}\text { The Good, the Bad and } \\
\text { the Ugly }\end{array}$} & $\begin{array}{l}\text { That Was the Week } \\
\text { That Was (NBC) }\end{array}$ & $\begin{array}{l}\text { National Endowment } \\
\text { of the Arts (NEA) }\end{array}$ & Mary McCarthy, \\
The Greatest Story & NBC's Get Smart & founded & Truman Capote, In \\
Ever Told & satirises spy genre & Archives of American & Cold Blood \\
The Sound of Music & The Smothers Brothers & Art founded & Malcolm X with Alex \\
wins Academy Award & Comedy Hour & Susan Sontag, 'On & Haley, The \\
for Best Picture & & Style' & Autobiography of \\
The Cincinnati Kid & James Rosenquist, & Malcolm X \\
& & F-111 & \\
& & Andy Warhol, Four & \\
& Campbell's Soup Cans & \\
& Warhol, Electric Chair & \\
& Warhol, Jackie & \\
& Sister Mary Corita \\
& (Frances Elizabeth & \\
& Kent), enriched bread & \\
& Wallace Berman, \\
& You've Lost That \\
& Loving Feeling
\end{tabular}




\begin{tabular}{|c|c|c|c|c|}
\hline Date & Events & Film & Performance & Literature \\
\hline 1966 & $\begin{array}{l}\text { Warren Commission } \\
\text { report on Kennedy } \\
\text { assassination. } \\
\text { James Meredith's } \\
\text { 'March Against Fear'. } \\
\text { National } \\
\text { Organization of } \\
\text { Women (NOW) } \\
\text { founded, Washington } \\
\text { DC. } \\
\text { Human Be-In, San } \\
\text { Francisco. } \\
\text { Black Panther party } \\
\text { founded, Oakland, } \\
\text { California. } \\
\text { 'Battle of Sunset } \\
\text { Strip', LA. } \\
\text { Medicare Act passed } \\
\text { to support citizens } \\
\text { over 65 with medical } \\
\text { needs. }\end{array}$ & $\begin{array}{l}\text { John Lennon states } \\
\text { The Beatles are now } \\
\text { more popular than } \\
\text { Jesus Christ } \\
\text { The Beatles farewell } \\
\text { concert, San } \\
\text { Francisco } \\
\text { Police attempt to } \\
\text { shut down James } \\
\text { Brown concert } \\
\text { because dancing is } \\
\text { 'obscene' }\end{array}$ & $\begin{array}{l}\text { Lenny Bruce dies of } \\
\text { heroin overdose } \\
\text { Dylan goes into } \\
\text { seclusion for year } \\
\text { and a half } \\
\text { Warhol's film } \\
\text { Chelsea Girls opens }\end{array}$ & $\begin{array}{l}\text { Truman Capote, In } \\
\text { Cold Blood } \\
\text { Thomas Pynchon, } \\
\text { The Crying of Lot } \\
49 \\
\text { Margaret Walker, } \\
\text { Jubilee }\end{array}$ \\
\hline
\end{tabular}




\begin{tabular}{llll}
\hline Film & Television & Art & Criticism \\
\hline Hollywood adopts & Star Trek begins on & The Artists' Tower of & Allan Kaprow, \\
age-based film ratings & NBC & Protest, Los Angeles & Assemblage, \\
Walt Disney dies & Batman (1966-8) & Noah Purifoy and & Environments and \\
The Chase & William F. Buckley & Judson Powell's 66 & $\begin{array}{l}\text { Happenings } \\
\text { What Did You Do in }\end{array}$ \\
hosts The Firing Line & Signs of Neon & Susan Sontag, Against \\
the War, Daddy? & & Robert Smithson, Tar & $\begin{array}{l}\text { Interpretation } \\
\text { Khartoum }\end{array}$ \\
Seconds & Pool and Gravel Pit & Richard Dyer \\
& Larry Burrows' & $\begin{array}{l}\text { McCann, Hollywood } \\
\text { photograph 'Reaching }\end{array}$ & in Transition \\
& Out' & Charlotte Perkins, \\
& & Robert Smithson, & Women and Economics \\
& & 'Entropy and the New & (1898) republished
\end{tabular}




\begin{tabular}{|c|c|c|c|c|}
\hline Date & Events & Music & Performance & Literature \\
\hline 1967 & $\begin{array}{l}\text { Martin Luther King } \\
\text { Jr's 'Riverside' speech } \\
\text { in which he openly } \\
\text { condemns war in } \\
\text { Vietnam. } \\
\text { The March on the } \\
\text { Pentagon anti-war } \\
\text { demonstrations. } \\
\text { Astronauts Gus } \\
\text { Grissom, Edward } \\
\text { White and Roger } \\
\text { Chafee killed during } \\
\text { test launch, Cape } \\
\text { Canaveral. } \\
\text { The 'Summer of } \\
\text { Love'. } \\
\text { Inner-city riots } \\
\text { Newark, NJ and } \\
\text { Detroit. } \\
\text { Loving and Loving } \\
\text { vs. State of Virginia. } \\
\text { Muhammad Ali } \\
\text { refuses the draft. } \\
\text { Senator Robert } \\
\text { Kennedy calls for halt } \\
\text { to bombing of } \\
\text { Vietnam. } \\
\text { Thurgood Marshall is } \\
\text { first African } \\
\text { American appointed } \\
\text { Associate Justice of } \\
\text { Supreme Court. } \\
\text { George Lincoln } \\
\text { Rockwell, founder of } \\
\text { American Nazi Party, } \\
\text { assassinated. }\end{array}$ & $\begin{array}{l}\text { Rolling Stone } \\
\text { magazine founded } \\
\text { Monterey Pop } \\
\text { Festival } \\
\text { Beatles' White } \\
\text { Album and Sgt. } \\
\text { Pepper's' Lonely } \\
\text { Hearts Club Band } \\
\text { The Monkees wins } \\
\text { Emmy }\end{array}$ & $\begin{array}{l}\text { Hair premieres on } \\
\text { Broadway } \\
\text { Tom Lehrer's final } \\
\text { concert } \\
\text { Muhammad Ali } \\
\text { stripped of } \\
\text { heavyweight boxing } \\
\text { title by World } \\
\text { Boxing Association } \\
\text { for having refused } \\
\text { draft and boxing } \\
\text { licence revoked. } \\
\text { First Human Be-In } \\
\text { staged in San } \\
\text { Francisco. }\end{array}$ & $\begin{array}{l}\text { William Styron, The } \\
\text { Confessions of Nat } \\
\text { Turner } \\
\text { John A. Williams, } \\
\text { The Man Who Cried } \\
\text { I Am } \\
\text { Richard Brautigan, } \\
\text { Trout Fishing in } \\
\text { America } \\
\text { Wallace Stegner, All } \\
\text { the Little Live } \\
\text { Things }\end{array}$ \\
\hline
\end{tabular}




\begin{tabular}{|c|c|c|c|}
\hline Film & Television & Art & Criticism \\
\hline $\begin{array}{l}\text { Bonnie and Clyde } \\
\text { The Graduate } \\
\text { In The Heat of the } \\
\text { Night } \\
\text { Medium Cool } \\
\text { Planet of the Apes } \\
\text { Don't Look Back } \\
\text { Monterey Pop } \\
\text { Cool Hand Luke } \\
\text { The Dirty Dozen }\end{array}$ & $\begin{array}{l}\text { Stones asked to change } \\
\text { lyrics for The Ed } \\
\text { Sullivan Show to 'Let's } \\
\text { spend some time } \\
\text { together' } \\
\text { Franceso Rosi's The } \\
\text { Odyssey }\end{array}$ & $\begin{array}{l}\text { Art in Public Places } \\
\text { Program established by } \\
\text { the NEA } \\
\text { Los Angeles County } \\
\text { Museum, 'American } \\
\text { Sculpture of the Sixties' } \\
\text { David Rockefeller } \\
\text { funds Business } \\
\text { Committee on the Arts } \\
\text { Claes Oldenburg, } \\
\text { Placid Civic } \\
\text { Monument } \\
\text { Chicago's 'Wall of } \\
\text { Respect' } \\
\text { Dennis Oppenheim, } \\
\text { Cut in Oakland } \\
\text { Mountain } \\
\text { John McCracken, Blue } \\
\text { Column } \\
\text { Michael Fried, 'Art and } \\
\text { Objecthood', Artforum } \\
\text { Sol LeWitt, } \\
\text { 'Paragraphs on } \\
\text { Conceptual Art', } \\
\text { Artforum }\end{array}$ & $\begin{array}{l}\text { Marshall McLuhan, } \\
\text { The Medium is the } \\
\text { Message } \\
\text { Roland Barthes' 'The } \\
\text { Death of the Author' } \\
\text { published in the US } \\
\text { Maurice Tuchman, } \\
\text { American Sculpture of } \\
\text { the Sixties } \\
\text { William F. Pepper's } \\
\text { 'The Children of } \\
\text { Vietnam' } \\
\text { Susan Sontag, 'The } \\
\text { Aesthetics of Silence' } \\
\text { John Galbraith, How } \\
\text { To Get Out of Vietnam } \\
\text { Arthur Schlesinger Jr, } \\
\text { The Bitter Heritage: } \\
\text { Vietnam and American } \\
\text { Democracy, 1941-1966 }\end{array}$ \\
\hline
\end{tabular}




\begin{tabular}{|c|c|c|c|c|}
\hline Date & Events & Music & Performance & Literature \\
\hline 1968 & $\begin{array}{l}\text { Assassination of } \\
\text { Martin Luther King } \\
\text { Jr in Memphis. } \\
\text { Assassination of } \\
\text { Senator Robert } \\
\text { Kennedy in Los } \\
\text { Angeles. } \\
\text { Democratic } \\
\text { Convention, Chicago, } \\
\text { Hubert Humphrey } \\
\text { nominated, } \\
\text { disturbances break } \\
\text { out. } \\
\text { Kerner Commision } \\
\text { Report on Civil } \\
\text { Disorders. } \\
\text { Richard Nixon } \\
\text { elected President. } \\
\text { Poor People's March } \\
\text { on Washington. } \\
\text { Vietcong Tet } \\
\text { Offensive. } \\
\text { National Student } \\
\text { Strike. } \\
\text { Fair Housing Act } \\
\text { passed. } \\
\text { Shirley Chisolm first } \\
\text { African American } \\
\text { woman elected to } \\
\text { Congress. }\end{array}$ & $\begin{array}{l}\text { Otis Redding, } \\
\text { 'Sitting on the Dock } \\
\text { of the Bay' } \\
\text { The Beatles, 'Hey } \\
\text { Jude' } \\
\text { James Brown, 'Say It } \\
\text { Loud, I'm Black and } \\
\text { I'm Proud' } \\
\text { Alan and John } \\
\text { Lomax, Folk Song } \\
\text { Style and Culture }\end{array}$ & $\begin{array}{l}\text { Tommie Smith and } \\
\text { John Carlos' } \\
\text { Olympic Protest } \\
\text { Hair premieres on } \\
\text { Broadway } \\
\text { Neil Simon, Plaza } \\
\text { Suite } \\
\text { The Boys in the } \\
\text { Band, Off- } \\
\text { Broadway }\end{array}$ & $\begin{array}{l}\text { Norman Mailer, } \\
\text { Armies of the Night } \\
\text { William Styron, The } \\
\text { Confessions of Nat } \\
\text { Turner } \\
\text { John Updike, } \\
\text { Couples } \\
\text { Gwendolyn Brooks, } \\
\text { Come to Mecca } \\
\text { Tom Wolfe, Electric } \\
\text { Cool-Aid Acid Test }\end{array}$ \\
\hline
\end{tabular}




\begin{tabular}{|c|c|c|c|}
\hline Film & Television & Art & Criticism \\
\hline $\begin{array}{l}\text { The Green Berets } \\
\text { 2001: A Space Odyssey } \\
\text { Finian's Rainbow } \\
\text { Night of the Living } \\
\text { Dead } \\
\text { Wild in the Streets } \\
\text { Story of a Three-Day } \\
\text { Pass }\end{array}$ & $\begin{array}{l}\text { 'Elvis' '68 Comeback } \\
\text { Special' on NBC } \\
\text { Of Black America on } \\
\text { CBS } \\
\text { Rowan and Martin's } \\
\text { Laugh-In begins }\end{array}$ & $\begin{array}{l}\text { Musuem of Modern } \\
\text { Art, 'The Art of the } \\
\text { Real 1948-1968' } \\
\text { Valerie Solanis shoots } \\
\text { Andy Warhol } \\
\text { Dwan Gallery, New } \\
\text { York City, } \\
\text { 'Earthworks' } \\
\text { (including Oppenheim, } \\
\text { Oldenburg, Smithson, } \\
\text { De Maria, LeWitt) } \\
\text { Rauschenberg, } \\
\text { Autobiography } \\
\text { Edward Kleinholz, The } \\
\text { Portable War } \\
\text { Memorial }\end{array}$ & $\begin{array}{l}\text { Joan Didion, Slouching } \\
\text { Toward Betblehem } \\
\text { Eldridge Cleaver, Soul } \\
\text { on Ice } \\
\text { Walter Benjamin's 'Art } \\
\text { in the Age of } \\
\text { Mechanical } \\
\text { Reproduction' (1936) } \\
\text { translated and } \\
\text { published in the US } \\
\text { Lucy Lippard and John } \\
\text { Chandler, } \\
\text { 'Dematerialization of } \\
\text { Art', Art International } \\
\text { Guy Debord, The } \\
\text { Society of the Spectacle } \\
\text { Eliot Porter, In } \\
\text { Wildness is the } \\
\text { Preservation of the } \\
\text { World (Sierra Club) } \\
\text { Stewart Brand, Whole } \\
\text { Earth Catolog } \\
\text { Ronald Berman, } \\
\text { America in the Sixties } \\
\text { John Barth,'The } \\
\text { Literature of } \\
\text { Exhaustion' }\end{array}$ \\
\hline
\end{tabular}




\begin{tabular}{|c|c|c|c|c|}
\hline Date & Events & Music & Performance & Literature \\
\hline 1969 & $\begin{array}{l}\text { US astronauts land on } \\
\text { moon; Neil } \\
\text { Armstrong the first to } \\
\text { walk on moon. } \\
\text { Stonewall 'riots', } \\
\text { Greenwich Village, } \\
\text { New York City. } \\
\text { Friends of the Earth } \\
\text { founded. } \\
\text { Massive anti-war } \\
\text { demonstrations, } \\
\text { Washington DC. } \\
\text { The Manson 'family' } \\
\text { murders actress } \\
\text { Sharon Tate and } \\
\text { friends, Los Angeles. } \\
\text { My Lai massacre of } \\
\text { March } 1968 \text { exposed } \\
\text { in New York Times } \\
\text { and Life. } \\
\text { Nixon announces first } \\
\text { withdrawal of troops. }\end{array}$ & $\begin{array}{l}\text { Woodstock Festival } \\
\text { Altamont Festival } \\
\text { Diana Ross leaves } \\
\text { The Supremes }\end{array}$ & $\begin{array}{l}\text { Neil Simon, The } \\
\text { Last of the Red Hot } \\
\text { Lovers } \\
\text { Butterflies Are Free } \\
\text { on Broadway }\end{array}$ & $\begin{array}{l}\text { Philip Roth, } \\
\text { Portnoy's Complaint } \\
\text { Symposium 'The } \\
\text { Black Artist in } \\
\text { America' } \\
\text { N. Scott Momaday, } \\
\text { House Made of } \\
\text { Dawn }\end{array}$ \\
\hline
\end{tabular}




\begin{tabular}{|c|c|c|c|}
\hline Film & Television & Art & Criticism \\
\hline $\begin{array}{l}\text { Easy Rider } \\
\text { Medium Cool } \\
\text { Midnight Cowboy } \\
\text { Alice's Restaurant } \\
\text { Butch Cassidy and the } \\
\text { Sundance Kid } \\
\text { The Wild Bunch } \\
\text { Marooned }\end{array}$ & $\begin{array}{l}\text { Sesame Street on PBS } \\
\text { ABC Movie of the } \\
\text { Week } \\
\text { The Johnny Cash Show } \\
\text { The Bill Cosby Show }\end{array}$ & $\begin{array}{l}\text { Leon Golub, studies } \\
\text { Napalm I, II and III } \\
\text { Metropolitan Museum, } \\
\text { 'Harlem on my Mind, } \\
\text { 1900-68' } \\
\text { Formation of Art } \\
\text { Workers Coalition } \\
\text { (AWC) } \\
\text { Formation of Women } \\
\text { Artists in Revolution } \\
\text { (WAR) } \\
\text { Robert Smithson, } \\
\text { Asphalt Rundown, } \\
\text { Rome } \\
\text { Walter De Maria, Las } \\
\text { Vegas Piece, Tula Lake, } \\
\text { Nevada }\end{array}$ & $\begin{array}{l}\text { Theodore Roszak, The } \\
\text { Making of a Counter } \\
\text { Culture } \\
\text { Vine Deloria, Custer } \\
\text { Died for your Sins } \\
\text { Harold Cruse, The } \\
\text { Crisis of the Negro } \\
\text { Intellectual } \\
\text { Parker Tyler, } \\
\text { Underground Film }\end{array}$ \\
\hline
\end{tabular}


